GPJI 4(1)(2020)

\title{
KEMAMPUAN KECEPATAN GERAK DAN DAYA LEDAK OTOT SISWA PPLP JATIM DI KEDIRI CABANG OLAHRAGA ATLETIK
}

\begin{abstract}
Nuke Meirawati ${ }^{1 \square}$, Siti Nurrochmah ${ }^{2}$
Universitas Negeri Malang nukemeirawati55@gmail.com

\section{Info Artikel}

Sejarah Artikel:

Diterima: April-2020

Disetujui: Mei-2020

Dipublikasikan : Juni-2020

Kata Kunci:

kecepatan gerak, daya ledak otot, atletik

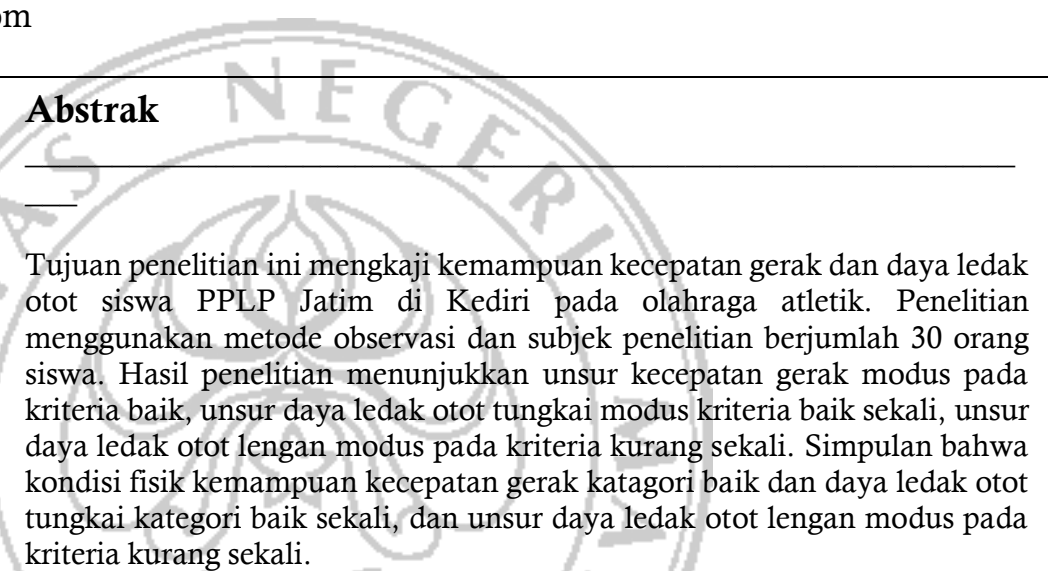

kriteria kurang sekali.

The purpose of this study is to examine the ability of the movement speed and muscle power of PPLP East Java students in Kediri athletic sports. The study used the method of observation and research subjects totaling 30 students. The results of the study showed that the speed of movement mode on the criteria of good, the element of the explosive power of the limbs of the mode of the criterion was very good, the element of the explosive power of the arm muscle in the criteria was very poor. The conclusion is that the physical condition of the ability of the speed of motion of the category is good, the leg muscle explosive power is very good category and the explosive power factor of the arm muscle mode is very poor criteria.
\end{abstract}

(C) 2020 Universitas Negeri Malang

\footnotetext{
Alamat korespondensi:

E-mail: nukemeirawati55@gmail.com
}

ISSN: 2614-8293 (Online) 


\section{PENDAHULUAN}

Olahraga merupakan kebutuhan hidup yang tidak bisa ditinggalkan dalam kegiatan sehari-hari. Olahraga adalah segala kegiatan yang sistematis untuk mendorong, membina serta mengembangkan potensi jasmani, rokhani dan social. Aktivitas olahraga yang dilakukan dapat berupa olahraga pendidikan, olahraga rekreasi atau olahraga prestasi. Khusus pada olahraga prestasi menurut Undangundang Sistim Keolahragaan tahun 2005 (Kemenegpora, 2009) Bab VI pasal 27 Ayat 5 menyatakan bahwa pembinaan dan pengembangan olahraga prestasi sebagaimana yang dimaksud pada ayat empat melibatkan olahragawan muda potensional dari hasil pemantauan, pemanduan, dan pengembangan bakat sebagai proses regenerasi.

Untuk memajukan olahraga prestasi Pemerintah Daerah dan atau masyarakat dapat mengembangkan perkumpulan olahraga misalnya sentra pembinaan olahraga prestasi. Dalam rangka menumbuhkembangkan prestasi olahraga di lembaga pendidikan, pada setiap jalur pendidikan dapat dibentuk unit kegiatan olahraga, kelas olahraga atau pusat pembinaan dan pelatihan.

Pembinaan atletik di Jawa Timudi untuk lingkungan pelajar di tempatkan di Kota Kediri yaitu tepatnya di SMA Negeri VIII Kediri. Sekolah tersebut memperoleh mandat dari Kantor Dispora Jatim untuk melaksanakan pembinaan olahraga prestasi dari lingkungan pelajar yaitu lembaga pusat pembinaan dan pelatihan pelajar (PPLP) Jatim pada cabang olahaga Atletik. Beberapa Siswa yang berprestasi pada olahraga atletik di tampung di SMA tersebut untuk mengikuti proses pembinaan yang sistematis dan berkelanjutan. Melalui upaya sentralisasi di Sekolah tersebut kegiatan pembinaan pada lembaga PPLP dimaksudkan sebagai upaya menemukan keunggalan dalam melakukan pembinaan, sehingga diharapkan siswa PPLP Jawa Timur akan mampu bersaing dengan tempat PPLP di lain Provinsi jika menghadapi event di lingkungan pelajar atau kelompok Yunior.

Setiono (2006) berpendapat bahwa Pusat Pendidikan dan Pelatihan Olahraga Pelajar (PPLP) dan Sekolah Khusus Olahragawan (SKO) merupakan lembaga pendidikan untuk menjaring dan membina pelajar berbakat olahraga agar dapat mencapai prestasi olahraga yang tinggi di tingkat nasional dan bahkan internasional. Prestasi olahraga yang tinggi hanya dapat dicapai oleh olahragawan yang mempunyai bakat besar dan memperoleh pembinaan yang baik secara berjenjang dan berkesinambungan dan dilakukan secara terencana, terprogram dan berjenjang yang dimulai sejak usia dini.

Pengelolaan PPLP harus menggunakan sistem degradasi dan promosi agar olahragawan yang dibina lebih berprestasi dan kompetitif (Jamalong, 2014). Beberapa faktor yang mempengaruhi prestasi olahraga meliputi faktor antropometri tubuh, faktor keterampilan, faktor kondisi fisik, faktor psikis juga termasuk kondisi kesehatan. Diantara faktor-faktor tersebut faktor kondisi fisik merupakan faktor yang sangat penting dalam menunjang unjuk kerja setiap olahragawan, sehingga penting untuk diperhatikan. Bompa \& Buzzichelli (2015) berpendapat bahwa kemampuan kondisi fisik yang mempunyai peranan penting untuk keberhasilan olahragawan berprestasi adalah unsur kekuatan, kecepatan dan daya tahan.

Harsono (2017b) mengatakan bahwa komponen kondisi fisik mempunyai peranan penting dan merupakan kunci penentu kinerja olahragawan, sehingga seharusnya unsur-unsur kondisi fisik penting diperhatikan dan dikembangkan sampai tingkat tinggi melalui latihan-latihan yang lebih intensif dan terprogram. Dalam olahraga atletik komponen kondisi fisik yang mempunyai kriteria sangat penting dan sebagai kunci penentu kinerja adalah unsur kekuatan otot tungkai, kecepatan gerak dan daya ledak otot tungkai, termasuk daya tahan otot dan daya jantung paru-paru (Pate dalam Nurrochmah, 2012). Berarti komponen-komponen tersebut penting untuk diperhatikan.

Siswa PPLP Jatim di Kediri merupakan olahragawan cabor atletik yang selalu mewakili Provinsi Jatim untuk mengikuti berbagai event kejuaraan atletik mulai kejuaraan Jatim Open, O2SN, PORPROV, POPDA dan Kejurnas antar PPLP termasuk POPNAS. Dalam rangka menyiapkan olahragawan mencapai prestasi pada berbagai kejuaraan tersebut, PPLP Jatim rutin melakukan latihan yang terprogram, sistematis, berkelanjutan dan latihan lebih difokuskan pada aspek kondisi fisik yang mendukung kinerja olahragawan seperti unsur kekuatan otot, kecepatan, daya tahan otot dan daya ledak otot disamping latihan teknik untuk masing-masing nomor.

Latihan adalah aktivitas fisik yang direncanakan, terstruktur, berulang-ulang dan bertujuan untuk memperbaiki atau memelihara komponen-komponen kebugaran jasmani (Niemen, 2011). Latihan yang diberikan secara rutin dilakukan dengan mengaplikasikan program-program latihan yang telah dirancang dengan tepat sesuai dengan tujuan latihan berdasarkan komponen fisik yang ditingkatkan. Harsono (2017a) berpendapat bahwa prencanaan suatu proses latihan seharusnya merujuk kepada prosedur yang dikelola dengan baik, metode latihan yang tepat dan ilmiah, sehingga 
program yang dirancang dapat membantu olahragawan untuk mecapai prestasi yang maksimal. Untuk menyusun program latihan yang tepat, seharusnya mengacu pada hasil latihan dalam kurun waktu tertentu dan dilakukan tes dan pengukuran secara berkala terhadap aspek kondisi fisik yang ditingkatkan untuk mengetahui perkembangan kondisi fisik setelah menerima program latihan. Kegiatan tes dan pengukuran merupakan bagian penting dalam pelaksanaan latihan untuk mengetahui kondisi fisik olahragawan.

Kegiatan pembinaan dan latihan pada cabor Atletik di PPLP Jatim hanya unsur kekuatan dan daya tahan otot yang sering dilakukan tes dan pengukuran, sedangkan unsur kondisi fisik lainnya seperti unsur daya ledak otot tungkai dan lengan termasuk unsur kecepatan gerak pelaksanaan tes dan pengukuran belum dilakukan secara berkala dan lebih condong mengoptimalkan aktivitas latihannya. Clark, et. al. (2015) berpendapat bahwa penilaian kinerja olahragawan berdasarkan hasil tes dapat digunakan untuk menilai secara objektif seluruh kinerja olahragawan. Adapun kemampuan fisik yang seharusnya dites berulang-ulang meliputi unsur kekuatan otot, kecepatan, daya ledak, kelincahan untuk digunakan dalam menyusun program kondisioning fisik yang baik.

Berarti dalam melaksanakan rangkaian tes dan pengukuran setelah pemberian program latihan adalah penting. Melaksanakan tes dan pengukuran pada unsur-unsur kondisi fisik yang dibutuhkan dalam cabor atletik adalah penting khususnya unsur kecepatan dan daya ledak karena kedua unsur kondisi fisik tersebut merupakan factor yang sangat penting dan kunci penentu unjuk kerja olahragawan pada cabor atletik.

Clark, et. al. (2015) berpendapat bahwa kecepatan adalah kemampuan untuk mencapai gerakan kecepatan yang tinggi. Kecepatan menurut Harsono (2017b) adalah kemampuan saat melakukan suatu gerakan dalam periode waktu secepat mungkin. Nieman (2011) berpendapat bahwa daya ledak otot adalah kecepatan seseorang dalam melakukan kerja. Bompa \& Buzzichelli (2015) mengatakan bahwa daya ledak otot adalah kemampuan seseorang melakukan gerak eksplosif dalam waktu yang sangat cepat. Daya ledak otot (power) adalah kombinasi antara unsur kekuatan maksimal dengan kecepatan yang dilakukan secara serempak (Nurrochmah, 2016). Kemampuan daya eksplosif otot dipengaruhi oleh unsur kekuatan dan kecepatan gerak.

Jadi dapat disimpulkan bahwa kecepatan gerak adalah kemampuan dalam menggerakkan keseluruhan tubuhnya secara berkesinambungan dengan -waktu tempuh yang secepat-cepatnya, sedangkan daya ledak otot lengan adalah gabungan antara unsur kekuatan dan kevepatan gerak.

Winarno (2009) telah melakukan penelitian tentang masalah "Pengelolaan Pusat Pendidikan Latihan Olahraga Pelajar (PPLP) Atletik Jawa Timur" fokus penelitian pada masalah model-model latihan dan capaian prestasi olahragawan PPLP Jatim cabang olahraga atletik. Hariyanto (2009) tentang masalah "Evaluasi Pelaksanaan Pusat Pendidikan dan Latihan Olahraga Pelajar". Idris (2016) melakukan penelitian tentang "Pembinaan Cabang Olahraga Atletik PPLPD Kabupaten Nganjuk".

Berdasarkan hasil observasi awal dan hasil penelitian tedahulu yang terkait dengan PPLP cabang olahraga atletik di Kota Kediri terdapat beberapa masalah terkait dengan unjuk kerja pada nomor lari, lompat jauh dan lempar. Ketika latihan rangkaian gerakan yang dilakukan unsur tertentu seperti kecepatan gerak dan daya ledak otot kurang optimal dan evaluasi dalam bentuk tes kurang dilakukan secara optimal. Masalah tentang pelaksanaan tes dan pengkuran pada unsur kecepatan gerak dan daya ledak otot yang kurang optimal penting dilakukan kajian melalui penelitian. Peneliti tertarik untuk melakukan pengukuran pada kedua unsur kecepatan gerak dan daya ledak otot tungkai dan lengan melalui penelitian.

Oleh karena permasalahannya yang dipaparkan di halaman terdahulu membahas tentang tes dan pengukuran yang kurang optimal pada kondisi fisik, kecepatan gerak, daya ledak otot dan olahraga atletik, maka peneliti mengkaji masalah tersebut melalui penelitian tentang "Kemampuan Kecepatan Gerak dan Daya Ledak Otot Siswa PPLP Jatim di Kediri pada Olahraga Atletik".

Tujuan penelitian ini adalah untuk mengkaji dan memperoleh informasi gambaran kondisi fisik unsur kecepatan gerak dan daya ledak otot siswA PPLP Jatim di Kediri pada Olahraga Atletik.

\section{METODE}

Rancangan penelitian menggunakan rancangan survey bentuk deskriptif kuantitatif. Instrumen penelitian menggunkan instrument tes dan pengumpulan data menggunakan teknik pengukuran bentuk tes yaitu tes kondisi fisik bentuk tes kecepatan gerak berupa tes lari 30 meter, tes daya ledak otot tungkai menggunakan tes loncat tegak lurus (vertical jump) dan untuk tes daya ledak otot lengan 
menggunakan tes lempar bola medicine tanpa awalan (Nurrochmah, 2016). Analisis data menggunakan statistika deskriptip bentuk tendensi sentral. Hasil tes dibandingkan dengan tabel normative merujuk buku panduan hasil tes dari Kemenegpora 2005 khusus untuk Siswa PPLP dan SKO.

\section{HASIL}

Analisis data pada ketiga butir tes yang meliputi tes (a) kemampuan kecepatan gerak lari 30 meter, (b) daya ledak otot tungkai dan (c) daya ledak otot lengan untuk siswa PPLP Jatim di Kota Kediri berjumlah 30 orang testi diperoleh bahwa hasil tes kecepatan gerak lari 30 meter untuk norma kriteria baik sekali terdapat $7 \%$, kriteria baik $43 \%$, kriteria sedang 32\%, kriteria kurang $14 \%$ dan kriteria kurang sekali $4 \%$ jadi untuk tes kecepatan gerak modus berada berada pada kriteria baik.

Hasil tes daya ledak otot tungkai pada norma kriteria baik sekali $100 \%$, kriteria baik $0 \%$, kriteria sedang $0 \%$, kriteria kurang $0 \%$, dan kriteria kurang sekali $0 \%$. Jadi untuk tes unsur daya ledak otot tungkai modus pada kriteria baik sekali. Hasil tes daya ledak otot lengan untuk norma kriteria baik sekali $0 \%$, kriteria baik $0 \%$, kriteria sedang $0 \%$, kriteria kurang 7\%, dan kriteria kurang sekali $93 \%$. Jadi untuk tes daya ledak otot lengan modus berada pada kriteria kurang sekali yaitu 93\%.

\section{PEMBAHASAN}

Cabang olahraga atletik merupakan aktivitas jasmani yang menjadi dasar untuk cabang olahraga lainnya seperti sepak bola, bola voli, bola basket, renang, pencak silat dan jenis olahraga lainnya. Warsidi (2009) menjelaskan bahwa atletik adalah gabungan dari beberapa jenis olahraga yang garis besar bisa dikelompokkan menjadi lari, lempar, jalan dan lompat. Unjuk kerja dalam Olahraga atletik sangat membutuhkan keberadaan kondi fisik.

Kondisi fisik merupakan salah satu syarat sangat dibutuhkan untuk kegiatan olahraga, terutama untuk mencapai prestasi yang optimal. Apriliyanto, dkk. (2016) menjelaskan bahwa kondisi fisik merupakan suatu persyaratan yang harus dimiliki oleh seorang olahragawan untuk meningkatkan dan mengembangkan prestasi olahraga yang optimal, sehingga kondisi fisiknya harus dikembangkan dan ditingkatkan sesuai dengan karakteristik dan kebutuhan masing-masing cabang olahraga. Cara untuk mengembangkan unsur kondisi fisik adalah melalui latihan. Melalui latihan hasilnya dapat membantu olahragawan untuk meningkatkan berbagai macam jenis keterampilan yang dimiliki oleh setiap olahragawan sehingga prestasi yang dicapai dapat maksimal (Harsono, 2017a).

Berdasarkan temuan di lapangan setelah data diperoleh dan dianalisis berikut dipaparkan pembahasan hasil penelitian untuk masing-masing komponen kondisi fisik yang telah dikaji.

Kemampuan Kecepatan Gerak Untuk Siswa PPLP Jatim Cabang Olahraga Atletik di Kota Kediri

Hasil tes kemampuan kecepatan gerak siswa PPLP Jatim cabang olahraga atletik di Kota Kediri, dari hasil tes kecepatan lari diperoleh 12 orang siswa (43\%) dari 30 orang katagori hasil tes dominan termasuk katagori baik (modus: 12 orang) (merujuk panduan parameter dari Kemenpora 2005). Hal ini berarti pada siswa PPLP Jatim di Kota Kediri cabang olahraga atletik, kemampuan kecepatan lari termasuk katagori baik. Seharusnya sebagai olahragawan hasil tes termasuk pada katagori baik sekali. Solusi yang tepat untuk mencapai kriteria baik sekali adalah melakukan latihan.Latihan adalah bentuk aktivitas fisik yang dilakukan oleh seseorang untuk mencapai kinerja tingkat tinggi yang akan dicapai oleh seorang olahragawan yang mempunyai kegiatan khusus (Clark, et al. 2015). Latihan yang sistematis dan baik seharusnya dilaksanakan secara teratur, terencana, terjadwal, menurut pola dan sistem tertentu dan berkesinambungan dari gerakkan sederhana menuju yang lebih kompleks.

Agar latihan-latihan tersebut dapat memberikan pengaruh pada kondisi fisiknya, maka bentuk latihan yang umumnya digunakan dapat ditambah dengan latihan beban. Latihan beban menurut Sugiharto (2014) adalah program latihan kekuatan dengan memberikan tahanan atau tekanan menggunakan beban seperti barbel dan dumbell, program latihan beban ini direncanakan untuk mengembangkan kekuatan otot.

Melatih kecepatan gerak olahragawan harus mempunyai kemampuan bertoleransi terhadap tingkat atau jumlah asam laktat yang tinggi, yang menyebabkan kelelahan otot. Toleransi tinggi terhadap asam laktat dapat dicapai dengan melakukan latihan anaerobik, bagi seluruh tubuh atau 
untuk kelompok bagian otot tertentu saja (Sugiharto, 2014).Untuk mendapatkan dan merubah peningkatkan kecepatan olahragawan ada 2 faktor yang harus diperhatikan, yaitu (1) kecepatan langkah dan (2) panjang langkah. Kecepatan langkah merupakan faktor yang paling penting dalam perkembangan maksimal kecepatan. Semakin cepat langkah dengan menapakkan kaki di tanah maka semakin meningkat kecepatan waktu yang baik dari sistem neoromuskular dan penampilan tingkat tinggi (Clark, et al 2015).

Terkait dengan latihan untuk meningkatkan unsur kecepatan terdapat beberapa hasil penelitian terdahulu dari para peneliti, seperti penelitian yang dilakukan oleh Fantiro dan Saputra (2015: 290308) yang meneliti tentang "Pengaruh Latihan Ladder Speed Run dan Shuttle Run terhadap Kecepatan dan Kelincahan", kesimpulan hasil penelitian dilaporkan bahwa latihan ladder speed run dan shuttle run terdapat pengaruh yang signifikan terhadap peningkatan kemampuan kecepatan dan kelincahan. Latihan ladder speed run lebih baik untuk meningkatkan kemampuan kecepatan gerak.

Terkait dengan hasil penelitian terdahulu tersebut dapat di kemukakan jika olahragawan menginginkan memiliki kecepatan gerak yang baik sekali, maka penting dan dibutuhkan latihan fisik yang sistematis dan terprogram serta berkelanjutan. Dengan demikian berdasarkan hasil temuan dari penelitian ini bahwa kondisi kemampuan kecepatan gerak yang diukur melalui tes lari 30 meter yang hasilnya rata-rata $43 \%$ dan modus kriteria berada pada kategori baik jika menghendaki kemampuan kecepatan gerak pada kriteria baik sekali, maka latihan fisik dengan menggunakan bentuk latihan yang tepat sebaiknya lebih di intensifkan dan dengan program-program latihan yang lebih baik.

\section{Daya ledak Otot Siswa PPLP Jatim Cabang Olahraga Atletik di Kota Kediri}

Tes daya ledak otot menggunakan tes loncat tegak untuk daya ledak otot tungkai dan lempar bola basket untuk menetahui kemampuan daya ledak otot lengan dilakukan untuk mengetahui seberapa besar kemampuan daya ledak otot siswa PPLP Jatim cabang olahraga atletik di Kota Kediri. Berdasarkan hasil tes daya ledak otot yang diikuti 30 orang olahragawan, menunjukkan bahwa pada tes daya ledak otot tungkai berada pada kriteria baik sekali terdapat 30 frekuensi (100\%). Berarti kondisi unsur daya ledak otot tungkai Siswa PPLP berada pada pada kategori baik sekali. Pada tes daya ledak otot lengan modus berada pada kriteria kurang sekali 28 frekuensi (93\%). Hal ini berarti pada siswa PPLP Jatim di Kota Kediri cabang olahraga atletik, untuk kemampuan daya ledak otot lengan termasuk katagori kurang (dibawah katagori baik), seharusnya sebagai olahragawan harus masuk pada katagori baik sekali. Oleh karena itu melihat kondisi real tersebut pelatih seharusnya melakukan pembenahan pada kemampuan kondisi fisik daya ledak otot lengan untuk mencapai katagori baik sekali misalnya pembenahan program latihan yaitu menambah porsi latihan.

Melihat kondisi daya ledak otot lengan hampir seluruh olahragawan katagori daya ledak otot lengan termasuk katagori kurang sekali, berarti daya lengan otot harus dan penting ditingkatkan melalui latihan-latihan yang intensif dan terprogram. Widiastuti (2015) mengatakan bahwa daya ledak otot sangat penting untuk lebih ditingkatkan melalui latihan-latihan yang lebih intensif. Hal ini disebabkan karena daya ledak otot lengan pada cabang olahraga atletik sangat dibutuhkan oleh olahragawan atletik nomor lapangan yaitu tolak peluru, lempar lembing, lontar martil, lompat tinggi galah dan lempar cakram.

Nurrochmah (2012) berpendapat bahwa daya ledak otot adalah daya eksplosif otot merupakan kombinasi dua unsur kondisi fisik yaitu kekuatan otot dan kecepatan gerak yang dilakukan secara serentak yang dihasilkan sebuah otot atau kelompok otot dalam waktu yang sesingkat mungkin.Clark et al. (2015: 629) mengatakan bahwa daya ledak otot adalah kemampuan menggunakan kekuatan maksimum dalam waktu yang sangat cepat.

Hasil analisis pada kondisi tersebut daya ledak otot lengan termasuk katagori kurang sekali, karena subjek penelitian dari 30 olahragawan 16 orang dari olahragawan nomor lempar, sehingga olahragawan yang bukan pelempar dominan hasil tesnya berada pada kriteria kurang sekali. Nurrochmah (2012) menjelaskan bahwa daya eksplosif mempunyai peranan penting antara lain (1) pengarahan tenaga yang eksplosif seperti nomor lempar cakram, tolak peluru, (2) aktivitas olahraga yang mengharuskan olahragawan menolak ke atas (mengangkat badan ke atas) dengan kata lain take of seperti gerakan smash, nomor-nomor lompat, loncat indah, (3) nomor-nomor yang ada unsur percepatan seperti lari, renang, balap sepeda, (4) nomor-nomor yang ada unsur mengangkat dengan cepat, seperti membanting lawan, angkat besi, (5) nomor-nomor yang ada unsur memukul, seperti tinju, silat, dan bisbal.

Daya ledak otot (Power) dapat ditingkatkan dengan melatih kedua komponen kemampuan biomotorik, gabungan kedua komponen pembentuk daya ledak. Untuk menghasilkan daya ledak yang optimal, latihan disarankan dilakukan dengan gabungan antara unsur kekuatan dan kecepatan yang 
dilakukan secara serentak seperti latihan plaiometrik (Bompa dan Buzzichelli (2015). Terdapat satu bentuk latihan atau teknik latihan yang harus dilakukan bila kita ingin meningkatkan power latihan, yaitu dengan latihan plyometrik. Plyometrik merupakan suatu bentuk latihan lanjutan (teknik latihan lanjutan) dan hanya diberikan oleh pelatih pada olahragawan yang telah memiliki tingkat kebugaran jasmani yang tinggi. Latihan-latihan plyometrik untuk tungkai biasanya melibatkan latihan lompat, loncat, lari angkat lutut, loncat satu kaki dengan gerakan yang cepat (bounding, jumping, skipping and hopping) dan untuk meningkatkan daya otot lengan disaran menggunakan bola seperti bola medicine (Clark, et al, 2015).

Kemampuan daya ledak otot tungkai pada siswa PPLP berada pada kriteria baik sekali. Kondisi tersebut penting dijaga dan dipertahankan. Untuk mempertahankan tersebut penting melakukan latihan secara intensif, karena daya ledak otot tungkai pada cabang olahraga atletik merupakan salah satu unsur kondisi fisik yang sangat penting dan merupakan kunci penentu kinerja olahragawan, sehingga penting untuk ditingkatkan dan dikembangkan melalui latihan-latihan yang teratur, sistematis dan terprogram, melalui latihan fisik bentuk latihan ketahanan (beban) sehingga unsur daya ledak otot menjadi lebih.

Terkait latihan daya ledak tersebut, terdapat beberapa hasil penelitian terdahulu tentang peningkatan daya ledak otot seperti yang dilakukan oleh Winarno (2009) telah melakukan penelitian pada pelajar PPLP Jatim cabang olahraga atletik kesimpulan hasil penelitian di lapangan bahwa model latihan atletik di PPLP Jatim disimpulkan cukup baik dan capaian prestasi kategori baik. Berarti dengan pelaksanaan latihan yang intensif prestasi yang dicapai termasuk kategori baik. Nurrochmah (2015) tentang "Efektivitas Pelatihan Beban Dinamis dan Statis Untuk Meningkatkan Kekuatan dan Daya Eksplosif Otot Tungkai dan Lengan"-kesimpulan hasil penelitian dilaporkan bahwa ada peningkatan yang signifikan kemampuan kekuatan dan daya eksplosif otot tungkai dan lengan akibat pelatihan beban dinamis dan statis. Pelatihan diagonal step lebih efektif meningkatkan kekuatan otot tungkai dan lengan. Pelatihan lateral hop lebih efektif meningkatkan daya eksplosif otot tungkai dan lengan. Pelatihan leg press cepat dan lambat efektif meningkatkan kekuatan dan daya eksplosif otot tungkai. Agar latihan berdampak pada peningkatan daya ledak yang ditingkatkan latihan yang diberikan sebaiknya berpedoman dan menerapkan prinsip-prinsip latihan fisik secara benar.

Penelitian yang dilakukan oleh Fantiro dan Saputra (2015: 290-308) yang meneliti tentang "Pengaruh Latihan Ladder Speed Run dan Shuttle Run terhadap Kecepatan dan Kelincahan", kesimpulan hasil penelitian dilaporkan bahwa latihan ladder speed run dan shuttle run terdapat pengaruh yang signifikan terhadap peningkatan kemampuan kecepatan dan latihan ladder speed run lebih baik peningkatan kemampuan kecepatan. Berarti latihan ladder speed/run dapat digunakan untuk meningkatkan unsur kecepatan. Kecepatan termasuk salah satu unsur pembentuk daya ledak otot, sehingga melalui latihan kecepatan dapat digunakan untuk meningkatkan unsur daya ledak otot.

Peneliti lain yang dilakukan oleh Khumaidah (2019) penelitian tentang Pengaruh Latihan Push $U p$ di ke dinding dan di Lantai terhadap Peningkatan Kemampuan Daya Ledak Otot Lengan, kesimpulan hasil penelitian dilaporkan bahwa ada pengaruh yang signifikan antara latihan Push Up di dinding dan di Lantai terhadap peningkatan kemampuan daya ledak otot lengan. Latihan push Up di lantai lebih baik terhadap peningkatan kemampuan daya ledak otot lengan. Latihan daya ledak otot dapat menggunakan dua cara yaitu (1) latihan kekuatan atau (2) latihan kecepatan gerak.

Perkembangan kondisi fisik melalui latihan-latihan amatlah penting, oleh karena tanpa keberadaan kondisi fisik yang baik olahragawan tidak akan mampu mengikuti latihan-latihan dengan sempurna. Tujuan utama latihan adalah meningkatkan potensi faaliah dan mengembangkan kemampuan biomotorik ke tingkat yang setinggi-tingginya agar prestasi dapat tercapai (Harsono, 2018).

Terkait dengan hasil penelitian terdahulu tersebut dapat di kemukakan jika olahragawan menginginkan memiliki kecepatan gerak yang baik sekali, maka penting dan dibutuhkan latihan fisik yang sistematis dan terprogram serta berkelanjutan. Dengan demikian berdasarkan hasil penelitian terdahulu yang telah dipaparkan, dapat dikemukakan bahwa jika temuan data dari lapangan hasil tes kriteria termasuk kategori kurang sekali, berarti latihan fisik sebaiknya lebih intensifkan dengan program latihan yang telah dirancang dengan baik dan terprogram serta tepat diberikan sesuai kondisi fisik yang ditingkatkan.

\section{KESIMPULAN}


Berdasarkan pada paparan hasil analisis data, maka penelitian ini dapat disimpulkan bahwa kondisi fisik siswa PPLP Jatim Kediri cabang olahraga atletik: (1) kemampuan kecepatan gerak dominan pada kriteria baik, (2) kemampuan daya ledak otot tungkai dominan pada kriteria baik sekali dan kemampuan daya ledak otot lengan dominan pada kriteria kurang sekali.

Berdasarkan hasil analisis data dengan temuan-temuan yang dihasilkan dalam penelitian ini, maka dapat dikemukakan saran bagi pelatih PPLP Jatim di Kediri cabor atletik, bagi siswa PPLP Jatim cabang olahraga atletik dan calon peneliti lainnya yaitu (a) Bagi Pelatih PPLP Jatim untuk memberikan program dan pelaksanan latihan yang lebih diintensifkan untuk program latihan kondisi fisik umum dan khusus, (b) bagi siswa PPLP Jatim meningkatkan program latihan yang lebih intensif dengan menerapkan program latihan dengan benar, (c) bagi calon peneliti lainnya melakukan kajian yang lebih detail dengan menambah unsur kondisi fisik lainny dalam bentuk penelitian lain.

\section{DAFTAR PUSTAKA}

Apriliyanto, S., Lusianti, S., Puspodadi, YNA. 2016. Profil Kondisi Olahragawan Junior Taekwondo PUSLATKOT KEDIRI Tahun 2016 dalam Menghadapi Pekan Olahraga Provinsi (PORPROV) Jawa Timur Tahun 2017. Jurnal Kejaora, 1 (2).

Bompa \& Buzzichelli. 2015. Periodization Training for Sports. Canada: Human Kinetic.

Clark, M.A., Sutton, B., Lucett, S.S. 2015. The Essentials of Sports Performance Training. Burlington: Jones \& Bartlett Learning.

Fantiro, F.A. \& Saputra, S.Y. 2015. Pengaruh Latihan Ladder Speed Run dan Shuttle Run terhadap Kecepatan dan kelincahan/Jurnal IPTEK OLAHRAGA. Vol. 17Nomer 3. September-Desember. Hal. 290-308.

Hariyanto, E. 2009. Evaluasi Pelaksanaan Pusat Pendidikan dan Latihan Olahraga Pelajar. Jurnal IPTEK OLAHRAGA. Vol. 11 Nomer 3. September. Hal. 233-235.

Harsono. 2017a. Kepelatihan Olahraga. Teori dan Metodologi. Bandung: P.T. Remaja Rosadakarya. Harsono. 2017b. Periodisasi Program Pelatihan. Bandung: P.T. Remaja Rosadakarya.

Idris, A. 2016. Pembinaan Cabang Olahraga Atletik PPLPD Kabupaten Nganjuk: Ilmu Kesehatan Olahraga. Vol. 4. No.4. Hal. 1-9.

Jamalong, A. 2014. Peningkatan Prestasi Olahraga Nasional Secara Dini Melalui Pusat Pembinaan dan Latihan Mahasiswa (PPLP). Jurnal Pendidikan Olahraga. 167 (3) 159-168.

Kemenegpora. 2005. Panduan Penetapan Parameter Tes Pada Pusat Pendidikan dan Pelatihan Pelajar dan Sekolah Khusus Olahragawan. Jakarta: Kementrian Negara Pemuda dan Olahraga Republik Indonesia.

Kemenegpora. 2009. Undang-undang Republik Indonesia Nomor 3 tahun 2005 tentang Sistem Keolahragaan Nasional. Jakarta: Kementrian Negara Pemuda dan Olahraga Republik Indonesia.

Khumaidah. 2019. Pengaruh Latihan Push Up di ke Dinding dan di Lantai terhadap Peningkatan Kemampuan Daya Ledak Otot Lengan. Malang: SKRIPSI. Tidak diterbitkan. Universitas Negeri Malang.

Nieman, D. 2011. Exercise Testing \&amp; Prescription. A Health-Related Approach. Seventh Edition. Toronto: McGraw Hill Companies.

Nurrochmah, S. 2012. Peningkatan Kekuatan dan Daya EksplosifOtot Tungkai dan Lengan Akibat Pelatihan Beban Dinamis dan Statis. Ringkasan Disertasi. Surabaya: Pascasarjana Universitas Negeri Surabaya.

Nurrochmah, S. 2015. Efektifitas Pelatihan Beban Dinamis dan Statis untuk Meningkatkan Kekuatan dan Daya Eksplosif Otot. Jurnal IPTEK OLAHRAGA. Vol. 11 Nomer 3. September. Hal. 236257 
Nurrochmah, S. 2016. Tes dan pengukuran dalam Pendidikan Jasmani dan Keolahragaan. Malang; UM Press.

Setiono, H. 2006. Panduan Penyusunan Latihan. Pusat Pendidikan dan Latihan Olahraga Pelajar dan Sekolah Khusus Olahragawan. Jakarta: Kemenegpora R.I.

Sigiharto. 2014. Fisiologi Olahraga. Teori dan Aplikasi Pembinaan Olahraga. Malang: UM Press.

Warsidi. 2009. Apakah Atletik itu. Bandung: Sarana Ilmu Pustaka.

Widiastuti. 2015. Tes dan Pengukuran Olahraga. Jakarta: PT. Rajagrafindo Persada.

Winarno, M.E. 2009. Pengelolaan Pusat Pendidikan dan Latihan Olahraga Pelajar. Jurnal IPTEK OLAHRAGA. Vol. 11 Nomer 3. September. Hal. 182-194.

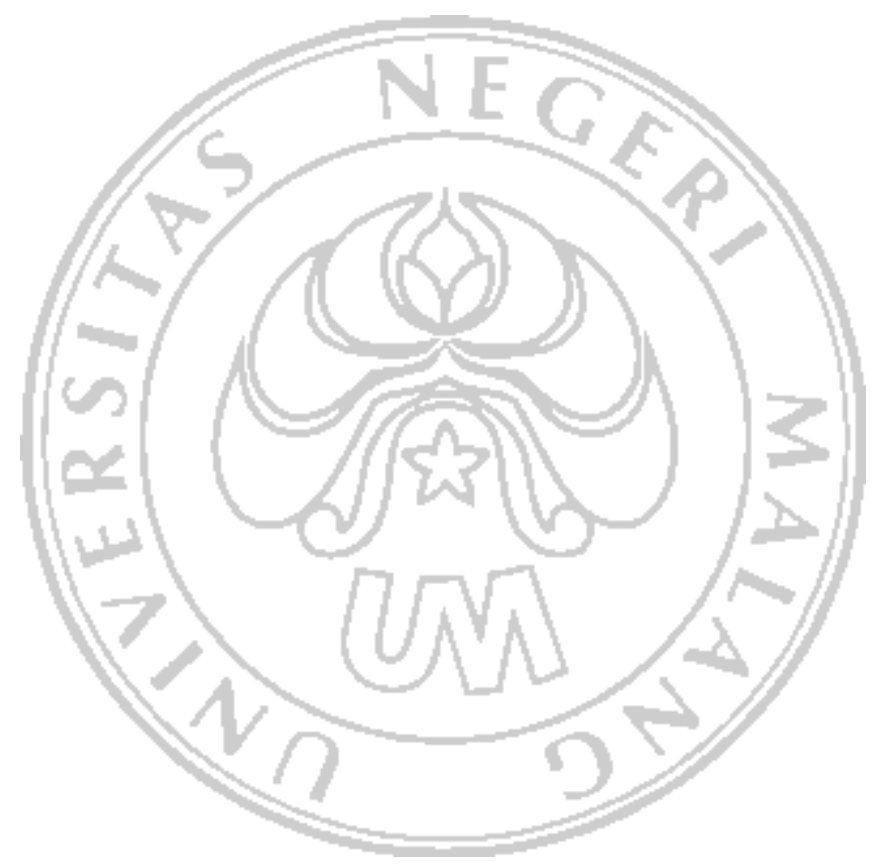

